\title{
A Revolutionary Cuisine: Food, Liberation \& Cubanidad
}

\author{
Ruth Masuka \\ University of Toronto \\ FAS Double Major in Diaspora \& Transnational Studies and Peace, Conflict \& Justice, \\ Minor in Music History \& Culture
}

\section{A B S T R A C T}

In one of his infamous speeches, Castro challenged Cubans with the question: "Why should we eat peaches? We were made to think that peaches were the best thing going and when we'd visit someone's house they'd offer us peaches. So we all thought that...peaches were better than mangoes, but peaches are expensive and foreign and mangoes are sweeter, cheaper, and much better." Castro's words spoke to how food, as an instrument of identity formation, allegiances, and community solidarity, is an intrinsic part of Cuba's history. In a Cuban context, food and cuisine can be understood as a site of resistance given the daily role food has in defining Cubanness. Its function goes beyond a mere biological necessity of nourishment and can be understood as a signifier of cultural capital, economic mobility, and social status. This paper seeks to demonstrate the ways in which food is so intertwined with music, religion, and other social institutions that it has become a storytelling practice of the narrative of Cuba's complex and nuanced historical, political, and socioeconomic realities. Food is not just a matter of what appeals to someone's taste, but a matter of what appeals to someone's ideologies. Cuba's cuisine is an informant in understanding the intersections between the choices of individuals, communities, and the state-at-large.

\section{$\mathrm{B}$ I O}

Ruth Masuka is a 3rd year student studying the intersections of peace and justice practices and art. Her research focuses on the use of non-institutional domains and informal spaces as catalysts for bottom-up group consciousness, capacity-building and community organizing. 
Even prior to Cuba's era of revolution, food served as a vehicle of hegemony, identity, and rebellion. The Spanish colonial regime made fervent efforts to replace indigenous foodways to no avail as the native cuisine was better suited to the physical environment and was strongly defended by the local population.1 Although their attempts to suppress indigenous cuisine proved to be mostly futile, it was still the perspective of Spanish imperialists that to eat too much of native foods was a return to the barbarism of the native people. Similarly, in the mass plantations, where African slaves were subject to inhumane treatment and forbidden from communicating, food became a medium of memory and tradition. Cuisine, as conceptualized by food anthropologist Sidney Mintz, is "the ongoing foodways of a region, within which active discourse about food sustains both common understandings and reliable production of the foods in question."2 Applied to the Cuban context, cuisine can be understood as a site of resistance given the daily role food has in defining Cubanness. Its function goes beyond a mere biological necessity of nourishment and can be understood as a signifier of cultural capital, historical relevance, economic mobility, and social status.

An example of a meal that remains a Cuban staple in the present-day, congri (rice and black beans) likely finds its roots in neighboring Haiti in the combination of

\footnotetext{
${ }^{1}$ Pilcher, J. M. (2012). Eating à la Criolla: Global and Local Foods in Argentina, Cuba, and Mexico. IdeAs, (3). doi:10.4000/ideas.406

2 Delgado, E. (2009, November 20). A Cuban Committees of Defense of the Revolution Celebration. Retrieved from: https://havanatimes.org/other-galleries/a-cuban-cdr-celebration/

3 Paponnet-Cantat, C. (2003). The Joy of Eating: Food and Identity in Contemporary Cuba. Caribbean Quarterly, 49(3), 11-29. doi:10.1080/00086495.2003.11672221

${ }^{4}$ Ibid

${ }^{5}$ Ibid

${ }^{6}$ Folch, C. (2008). Fine Dining: Race in Prerevolution Cuban Cookbooks. Latin American Research Review, 43(2), 205-223. doi:10.1353/lar.0.0029

the words "Congo" and "rice" (riz, French). This suggests the name came from when rice and beans was a common meal for slaves as it provided sustenance and protein. ${ }^{3}$ Through the conucos y crías system, some plantation owners provided tiny plots of land to slaves to grow their own food rather than having to provide them food. ${ }^{4}$ This allowed for the preservation of African farming practices and produce. Beyond maintaining identity through the land, African food traditions were fortified through song with hymns sung during the long grueling work slaves endured daily. ${ }^{5}$ The close association between food, music, and Afro-Cuban existence illustrates how culinary and melodic practices have served as forms of resistance against dominant ideologies even preceding the Revolution. ${ }^{6}$ In many ways, the culture of the revolution was nourished in these everyday acts of defiance in sustaining African and indigenous food heritages against the colonial regime. Through these and other examples, this research seeks to demonstrate the importance of food and cuisine as a fluid representation of Cuban identity and values at the intersections of individual, community-based, and state-level choices. 
It is important to note the food imageries specific to the Cuban context and their origins. Colonial legacies are still evident within Cuba's cuisine. Although Cuba's geography and climate would make it more conducive to being a fish-eating population, Cubans still tend to have a taste for meat. ${ }^{7}$ However, at the start of Castro's Revolution, killing cows for meat consumption was outlawed due to the need for milk as well as transportation. More importantly, this shift in food patterns reflects a political connotation against traditional colonial cuisine. Another food product with clear colonial connotations is sugar. The cooking of sweet dishes came to resemble the gayapo (sugar cane juice) slaves were given as their only food while working the plantation. ${ }^{8}$ José Martí, the infamous writer and considered the father of Cuban independence, conveyed a clear distaste for sugar in his works, preferring the wild honey used to make "Cuba-Libre". This was a symbolic rejection of the colonial economy and a celebration of both a free land and free people. ${ }^{9}$

As the fever of revolution spread throughout Cuba, food imageries transformed from traditional colonial dishes to the produce of the people. Stews like ajiaco and caldoza, arising from African heritage, illustrate the shift from a cuisine once defined by slave labor and hegemonic forces to foodways reflective of the variety of the Cuban population. Prepared with whatever available produce native to the land, the stew models the multidimensional identity and the continual struggle against hegemonic forces. Another fundamental ingredient that serves as a paradigm of culture and identity in Cuba are viandas, which cover the numerous root vegetables native to Cuban soil. They are believed to hold medicinal powers and have also been an integral part of smallholder independent farming in $\mathrm{Cuba}^{10}$ These foods are accompanied by the emblematic drinks in Cuba, especially coffee, rum, and beer. Coffee, being a mainstay of the economy, marks the closing of a meal and a sense of community and social inclusion. ${ }^{11}$ Beer has grown in meaning as a signifier of special occasions and the transition from work to social times of leisure. To speak of Cuban food traditions without the mention of rum would make for an incomplete narrative. As one of the most enduring legacies of the sugar and slave economy, rum has come to the transfer of power into the people's hands and with that, the resources of the land.

It is important to note that Cubans often prefer homemade rum or from local sources like neighbors, although lower quality, to brand names like Havana Club, as a testament to the devotion of local products and the communal network. Food's value in times of revolution is celebrated by Cubans to this day. Such as commemorating historical moments like the 1960 Committees of Defense of the Revolution (CDR), which was the largest mass organization in Cuban history. Annually, caldoza, the cultural stew of Cuba, is assembled among communities

\footnotetext{
${ }^{7}$ Paponnet-Cantat 2003

8 Ibid

9 Dawdy, S. L. (2002). 'La Comida Mambisa': Food, farming, and Cuban identity, 1839-1999. New West Indian Guide / Nieuwe West-Indische Gids, 76(1-2), 47-80. doi:10.1163/13822373-90002543

${ }^{10}$ Ibid

${ }^{11}$ Paponnet-Cantat (2003)
} 
using the produce everyone has to offer, symbolizing the revolutionary bond between the nation, neighborhoods, and homes. The linkages between specific foods and other daily activities of Cuban life exemplify both the individual and communal construction of identity.

Beyond the varied meanings of Cuban foods, there is a strong link between the local farmers who cultivate the land. Known as sitierios, the very existence of the owners of small plots of land entailed a form of resistance against colonial forces that have now replaced by capitalist forces of globalization. Given the long era of slavery in Cuba, land ownership has always been a reflection of autonomy and independence. Following their crusade for freedom, former African slaves purchased small farms to produce food for their families. At the start of Castro's Revolution, the figure of the peasant farmer became the Cuba hero. The province of Oriente, where $41 \%$ of sitieros were Afro-Cuban was entitled the "most Cuban region of all of Cuba." With agrarian reform and food security being main priorities of the socialist government, small farmers embodied emancipation and self-sufficiency. The overlap of the ex-slave, sitiero, and soldier, is once again a testimony to the multiplicity of Cuban character.

A valuable source of knowledge in appreciating the nuanced dimensions of food in Cuba is cookbooks. If understood as a historical document, cookbooks serve as "windows into kitchens of the past." was a common strategy of colonial governments to use written text to legitimize their rule while simultaneously marginalizing existing native cultures. ${ }^{14}$ The kitchen was by no means excluded from this. This is especially of significance in Cuba, where cooking knowledge historically took the form of oral practices rather than written form. Earlier cookbooks reflect the forced notions of Cuban identity which revolved around European cosmopolitan cuisine. Later editions begin to include traditional African dishes along with the foodways of the Taíno people, the principal inhabitants of Cuba. The presence of Cuban produce like viandas was of great symbolic importance as a shift of power from the periphery. During the Revolution, the cookbook became a text fraught with political implications. Nitza Villapol, a Cuban cookbook author who was a staunch advocate of the socialist government, created recipes using the foods rationed by, for example, offering a way to make tamales out of the imported Russian oats. ${ }^{15}$ Food as a mechanism of patriotism, in turn, makes the cookbook a tool of the production of ideologies. The cookbook transformed a national cuisine into a nationalist cuisine.

The political praxis of food arguably reached its height during the Período especial also known as the Special Period in Time of Peace at the start of the 1990s. What was meant to be a temporary phase of crisis after the fall of the Soviet Union, Cuba's largest partner in both trade and

\footnotetext{
${ }^{12}$ Dawdy (2002)

${ }^{13}$ Fuster, M. (2015). Writing Cuisine in the Spanish Caribbean: A Comparative Analysis of Iconic Puerto Rican and Cuban cookbooks. Food, Culture \& Society, 18(4), 659-680. doi:10.1080/15528014.2015.1088195

${ }^{14}$ Anderson, B. R. (1982). Imagined communities. London.

${ }^{15}$ Pilcher (2012).
} 
ideologies, lasted up until the turn of the century. The communal practices of preparing and eating food were reduced to attempts to fulfill increasingly unmet physical demands of nourishment. ${ }^{16}$ Although the food rationing system was meant to provide a sufficient standard of food items, it was more optimistic than realistic and forced Cubans to meet their needs through the black market. Due to the illicit nature of meeting food needs, the very acts of preparing, consuming, and enjoying food was limited to behind the closed doors of the family kitchen, shrouding a once communal and social space with secrecy because it did not operate according to legal norms! ${ }^{17}$ This era, also referred to as "La temporada de vaca flaca" (Skinny Cow Period), caused mass anxiety over food that induced a moral dilemma as Cubans found themselves torn between feeding their immediate family or sharing what little they had with friends and neighbors. This social erosion was captured in a common saying of the time: " si una visita no avisa, es un caos político; no se puede atender de la manera que quieres." (an unannounced visit is political chaos; it can't be looked after as one would wish it) ${ }^{18}$ While the physical effects of food scarcity were drastic, the social ramifications of the crisis went to show food's function as a site of community organization.
While the Special Period perpetuated and exacerbated food insecurity, it also provided a return from the government's investments in education and social services. At the onset of the crisis, Cuba accounted for only $2 \%$ of the Latin American population but $11 \%$ of the region's scientists 19 Cuban agronomists, supported by agricultural government policies in favor of developing local, grassroots solutions, produced technologies to improve systems of both rural and urban farming in matrimony between environmental sciences and the needs of the people. In both a figurative and literal sense, agricultural reform flourished through the community networks where exchanging produce and goods was a common occurrence. In sharp contrast in the United States of America where millions of empty homes, unoccupied skyscrapers, and vacant parking lots are held tightly by corporations, the Cuban government turned over private land unless it was put to use. ${ }^{20}$ Through such policies, hundreds of unused lots, many previously overrun with garbage, have been transformed into green spaces and sites of food production. This also allowed for a rebuilding of community ties lost due to food scarcity as gardeners would share the fruits of their labor with neighbors and friends. The pride of self-reliance and the generosity one could show because of it soon made home gardens a reflection of the owner's sociocultural status, health,

\footnotetext{
${ }^{16}$ Wilson, M. (2012). Moral Economies of Food in Cuba. Food, Culture \& Society, 15(2), 277-291. doi:10.2752/175174 $412 \times 13233545145345$

${ }^{17}$ Alfonso, I. D. (2014). We are What We Now Eat: Food and Identity in the Cuban Diaspora. Canadian Journal of Latin American and Caribbean Studies, 37(74), 173-206. doi:10.1080/08263663.2012.1100600

${ }^{18}$ Paponnet-Cantat (2003)

${ }^{19}$ Altieri, M. A., Companioni, N., Canizares, K., Murphy, C., Rosset, P., Bourque, M., \& Nicholls, C. I. (1999). The greening of the "barrios": Urban agriculture for food security in Cuba.Agriculture and Human Values, 16(2), 131-140

${ }^{21}$ Buchmann, C. (2009). Cuban Home Gardens and Their Role in Social-Ecological Resilience. Human Ecology, 37(6), 705-721. doi:10.1007/s10745-009-9283-9
} 
and their commitment to the well-being of their families and communities. ${ }^{21}$ At a macro-level, these gardens also reflected a dedication to the land and in this sense, an extension of the revolutionary notion of reaping what one sows.

Cuba currently finds itself, along with the rest of the world, at a critical juncture. The dominant systems of capitalism have been called into question due to its incapacity to mediate crisis, the ongoing climate crisis, and recurring global financial catastrophes. Cuba's geopolitical position has always made it a case study in how two opposing systems co-exist, creating polarities between Cuba as a place for Cubans and Cuba as an economic space "with both affinity and aversion to metropolitan capital, commodities, and values." 22 Food serves as another site of negotiation between these two discrepancies. Looking toward the island's future in a post-pandemic recovery, tourism as one of Cuba's major economic sectors will be critical. Restaurants, once looked down upon as capital enterprises pandering to the West, were revived with Raul Castro's economic reform policies and have in turn shown the potential role of self-employment activities in fostering a productive Cuban economy. ${ }^{23}$ Beyond the added economic benefits, paladres, the private restaurants often catered for international visitors, facilitate investments into peasant farmers and urban gardeners through restaurant purchases. Cuban agrarian policies and the growth of urban gardening have exemplified how a crisis-induced solution of

22 Wilson (2012)

${ }^{23}$ Deere, C. D., \& Royce, F. S. (2019). Provisioning Cuba's Private Restaurants: Linking Tourism and Agriculture. Tourism Planning \& Development, 16(6), 675-695. doi:10.1080/21568316.2019.1569120

24 Thiemann, L., \& Spoor, M. (2019). Beyond the "special period": Land reform, supermarkets and the prospects for peasant-driven food sovereignty in post-socialist Cuba (2008-2017). Canadian Journal of Development Studies / Revue Canadienne Détudes Du Développement, 40(4), 546-563. doi:10.1080/02255189.2019.1632174 small-scale agriculture and peasant agency can be consolidated and further stimulated in a phase of economic recovery. ${ }^{24} \mathrm{At}$ a microlevel, Cuban practices of eating have once again become an act of defiance towards the new dominant ideologies of globalization and neoliberalism as consumers' adaptation to normative pressures for convenience, casualness, and speed, implicit in practices of the fast-food industry, has drastically altered food habits, family life, and consumption rituals. In between community and commodity, food can be understood as an indicator of Cuba's future political and socioeconomic systems.

If these narratives of food tell us anything, it tells us this: the authenticity of Cubans lie in the people. In the words of Cuba's national hero, José Martí, "the wine is sour, but it is our wine." Food as a form of storytelling, neighborhood building, and defying dominant systems of power goes to show how the everyday acts of Cubans are embedded with liberation and solidarity. It is democracy in its most potent form, as everyone must eat. How one goes about community ties, and a broader sense of loyalty to different institutions. The variety of Cuban cuisine is a reflection to the complexities and nuances of Cuban identity that come together, at times in conflict and at times in harmony, to create a rich, vivid and unique imagery rooted in the people and the land they cultivate. doing so is a testament to their values, 